\title{
Advocacy Coalition Framework of Ultra Micro Loan Policymaking in Indonesia
}

\author{
Nining I Soesilo \\ Faculty of Economics and Business, University of Indonesia, Indonesia \\ Corresponding email: nining76@ui.ac.id \\ doi) http://dx.doi.org/10.22515/shirkah.v6i1.412
}

\begin{tabular}{|c|c|}
\hline ARTICLE INFO & ABSTRACT \\
\hline $\begin{array}{l}\text { Keywords: } \\
\text { Advocacy Coalition } \\
\text { Framework; Development } \\
\text { Planning and Policy; Financial } \\
\text { Markets and Institutions; } \\
\text { Microfinance; Political } \\
\text { Economy; Provision and Effects } \\
\text { of Welfare Programs } \\
\text { Article history: } \\
\text { Received: } 26 \text { March } 2021 \\
\text { Revised: } 13 \text { April } 2021 \\
\text { Accepted: } 14 \text { April } 2021 \\
\text { Available online: } 16 \text { April 2021 } \\
\text { To cite in APA style: } \\
\text { Soesilo, N. I. (2021). Advocacy } \\
\text { Coalition Framework of Ultra } \\
\text { Micro Loan Policymaking in } \\
\text { Indonesia. Shirkah: Journal of } \\
\text { Economics and Business, 6(1), 115- } \\
\text { 136 }\end{array}$ & $\begin{array}{l}\text { Advocating the Ultra Micro-lending concept of Indonesia's } \\
\text { Ministry of Finance in } 2017 \text { was a tumultuous nine-year } \\
\text { process. The present paper aims to examine the Ultra Micro- } \\
\text { lending (UMi) program conducted by the Ministry of Finance } \\
\text { of Republic of Indonesia using Advocacy Coalition } \\
\text { Framework. This paper showed that Advocacy Coalition } \\
\text { Framework could moderate the interest groups' } \\
\text { disagreement through seven steps as follows. First, relatively } \\
\text { stable parameters of poverty need alleviation using better } \\
\text { financial access with empowerment. Second, the external } \\
\text { system is inspired by Grameen Bank as the winner of the Nobel } \\
\text { Peace Prize. Third, removing constraints and resources of } \\
\text { subsystem actors from the internal Ministry of Finance and the } \\
\text { Parliaments. Fourth, creating consensus for getting the } \\
\text { Ministry of Bureaucratic Reform's permit. Fifth, policy } \\
\text { subsystem that coalesces the need of market-rate and } \\
\text { subsidized rate to cater to } 46.7 \text { million grassroots entrepreneurs } \\
\text { as a 'win-win' arrangement to complement the bank-based } \\
\text { People's Business Credit (KUR). Sixth, policy outputs as the } \\
\text { legal product of the UMi with a } 7 \text { Trillion State budget. } \\
\text { Seventh, policy impact's measurement after one year piloting } \\
\text { before UMi's scaling up. This paper has a significant } \\
\text { contribution to enhancing the efficacy of UMi program, and as } \\
\text { a continuous effort to ensure the economic development of the } \\
\text { country. }\end{array}$ \\
\hline
\end{tabular}

This work is licensed under a Creative Commons Attribution-NonCommercial 4.0 International License.

\section{Introduction}

In 2014, Usaha Kecil Mikro Center (henceforth UKMC), Faculty of Economics and Business, University of Indonesia (FEUI), a University-based Civil Society Organization, was invited by the Ministry of Finance during the first year of Jokowi as president of the Republic of Indonesia. At that time, nearly $13.8 \%$ of the Indonesian 
population was rural poor who primarily engaged in agriculture work. They comprised about $35 \%$ of the national labor force involved in low-end service with low productivity. Meanwhile, nearly $8.2 \%$ of the urban population is poor. Compared to the average GDP growth, the agricultural sector has slowed down considerably. In 1997-1998, during the Asia Financial Crisis, the Gini coefficient climbed from 0.31 in 2000 to 0.43 by 2013 (Aji, 2015). Panel data on 285 districts (Municipalities/Regions) in Indonesia showed about 0.7 growth elasticity of poverty; in other words, a $10 \%$ increase in economic growth is shown to raise the poor's income only 7\% (Balisacan et al., 2002). Hence, encouraging economic growth alone would create more unbalanced income. Indonesia's poverty line was analogous to the most impoverished countries of sub-Saharan Africa. Data from 104 countries between 1970 and 2010 shows that if the Gini coefficient (as an income inequality measurement) rises by one percentage point, the average real GDP per capita in a middle-income country will fall by $1.1 \%$ over five years (Brueckner \& Lederman, 2015). Such as scenario would prove disastrous for a middle-income country like Indonesia with $\$ 10,500$ of GDP per capita (in 2011 PPP dollars) because the rapid and substantial rise in inequality can potentially impact the country's future growth (Yusuf \& Sumner, 2015).

The Inclusive Financial Index showed that Indonesia reached only 36\% regarding financial deepening and inclusion. Indonesia lags behind some ASEAN countries, such as Thailand (78\%) and Malaysia (81\%), although it is more significant compared to the Philippines (31\%) and Vietnam (31\%) (ekon.go.id). The Ultra Micro-lending (henceforth UMi) program is designed to cater to the residual 46.8 million or $78.11 \%$ of total micro, small, and medium enterprises (MSME) in Indonesia who People's Business Credit (KUR) did not serve due to the bank's stringency as its intermediary. Public policy is related to the quality of life regarding whether inequality is tolerable through anticipated citizenship offered by the society (Hoppe, 2007: 342). Therefore, the Indonesian government introduced the National Medium-Term Development Plan and set an explicit target to achieve a Gini coefficient of 0.36 by 2019. In 2018, the Gini coefficient was 0.41 . The government established a $7-8 \%$ target for the national poverty rate by 2019 by creating employment opportunities, providing essential services, and framing social protection policies (Bappenas, 2014).

A "poverty trap" is the main reason for deprived families concentrated in countries and communities. Sachs et al. (2004) mentioned that they need financial access. The main problem is that when poverty is so extreme, the poor cannot get out of the trap. In particular, girls and women in most of the more inferior parts of the world are trapped in poverty and early marriage, with illiterate mothers giving birth to illiterate girls who have married early into the cycle of poverty, illiteracy, fertility, and other premature deaths (Power \& Maclean, 2013). Hence, UMi should combine financial 
access with entrepreneurship coaching and empowerment. UMi targets microentrepreneurs using the IDR 1.5 Trillion for the 2017 fiscal year as written since 12 October 2016, about Law 1, 2016 of the state budget, catering to 300,000 to 1,132,930 micro-entrepreneurs. The UMi debtors will increase to 13,595,157 micro-entrepreneurs in five years, about $75 \%$ of whom are new nonbankable customers who have never received bank-based People's Business Credit (KUR). UMi obliges all Non-Bank Financial Institutions that disburse UMi to be in healthy condition and should have entrepreneurship training to create qualified entrepreneurs to get out of the poverty trap. Unlike Grameen Bank, UMi serves women and men. For women with the Grameen bank method, they receive high-touch assistance through a pre-requisite five days "Grameen bank school." It is done before lending is disbursed and repeated weekly together with repayment schedule as a credit risk abatement effort. UMi is a complement of the KUR program because the financial gap of Indonesia was at US\$330 billion for Micro, small and medium enterprises (World Bank, 2017). Panda (2016) added trust in the microfinance study's three central themes: program influences, the impact outcome, and the intermediation roles. However, none of them elaborates the microfinance policymaking process. Hence, this paper tries to fill this gap. In 2015, the Faculty of Economics became Faculty of Economics and Business (FEB) University of Indonesia. For further elaboration, UKMC FEB UI is called UKMC.

\section{The Advocacy Coalition Framework}

The Advocacy Coalition Framework (ACF) is a framework established to manage complicated public policy problems (Weible \& Sabatier, 2007). In many countries, ACF has been demonstrated to be one of the extra convenient public policy frameworks (Schlager, 1995; Schlager \& Blomquist, 1996; Johns, 2003). In 2009, based on a University grant Program, UKMC FE UI advocated the UMi concept as a government program.

ACF encouraged policy communities to participate in the policy process, such as professional experts and others who thoroughly monitor and contribute in discussions about a policy problem. The participants of these groups allocate joint interests and care for the specific issue area and are occupied in several means in bringing about policy variation. This framework focuses on ideas and solutions for policy reform, such as a group holds a vital role in defining the negotiations about public policy, especially in the policy agenda-background and policy development segment of the policymaking process. ACF consists of: (1) Relatively Stable Parameters, (2) External System, (3) constraints and resources of subsystem actors, (4) degree of consensus needed for significant policy changes, (5) policy subsystem, (6) policy outputs, and (7) policy impacts. 
Relatively Stable Parameters consist of essential characteristics of the problem range, fundamental socio-cultural values and social structure, and basic constitutional structure. External factors consist of significant socioeconomic changes, changes in public opinion, changes in the systematic governing coalition, and policy decisions and impacts from other subsystems. Constrains consist of the theory of rational person when doing the policymaking. Complete control is known to the personal human beings who do not have a limitation of social order. In neoclassical economics, from political economy to rational choice theorizing, unambiguousness is attained in different ways. Even though they look to be fully autonomous, they have the rationalities to chase general societal pleasure. The degree of consensus has to consider a higher degree of the predictable fight of the entry to these policy linkages is disturbed. However, a policy subsystem often contains the plural network. The advocacy coalitions then contest for the supremacy network in the particular policy domain. Meanwhile, the policy subsystem is described by its protective boundary, a practical topic, and by a lot of policy contributor from all layers of government, numerous interest groups, the media, and research institutions, policy inputs, and policy output.

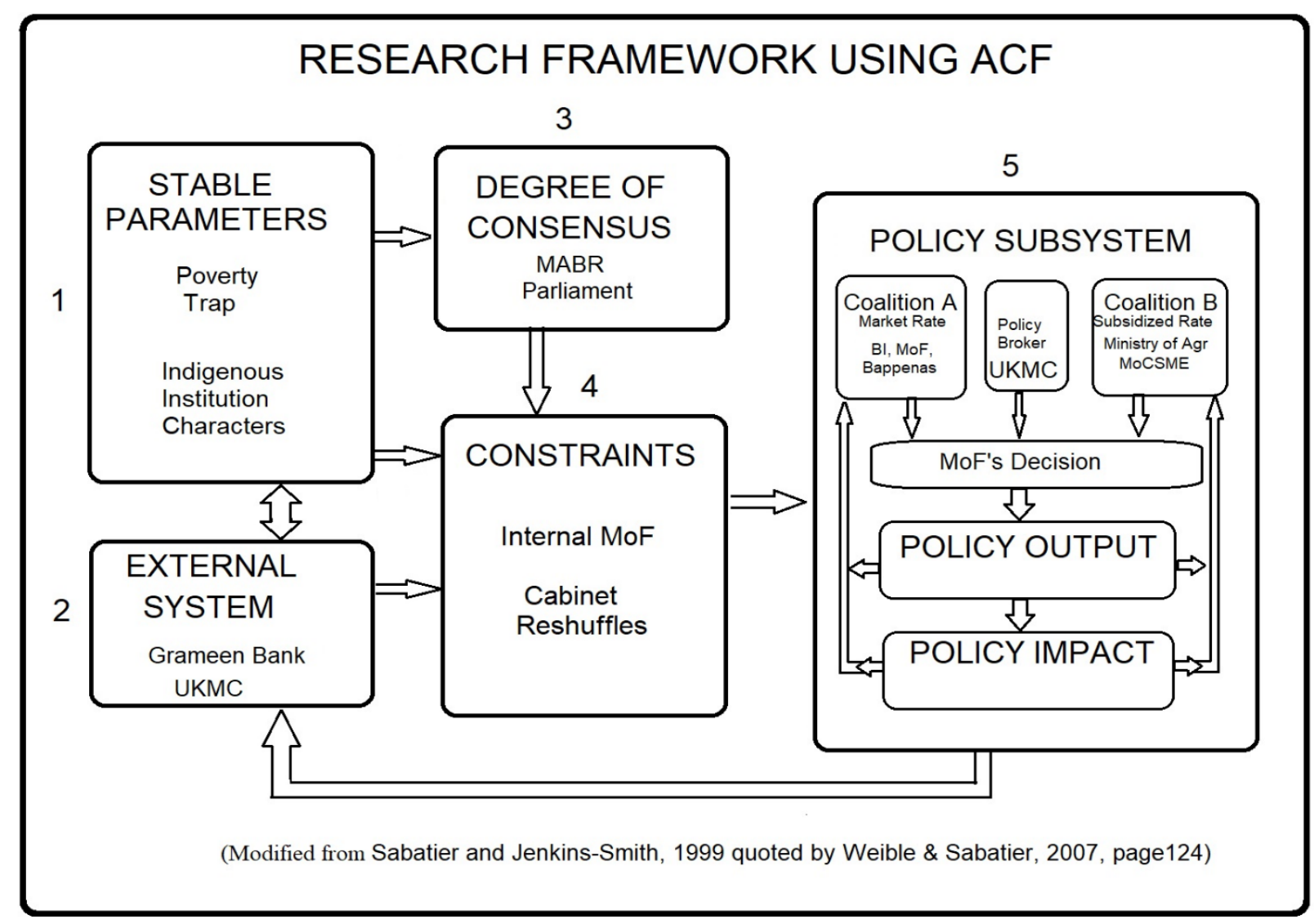

Figure 1. Research Framework using ACF 


\section{Analysis and Discussion \\ Relatively Stable Parameters}

The institutional stability that influences the UMi policymaking is through solving the informal, formal and humanly devised constraints as the first aspect scrutinized in North's institutional change theory (North, 1991). The rational choice theories clarify that institutional stability control actors reduce information costs and give casings for focal points that collectively enable actors' harmonization and cooperation and reasons for the equilibrium (North, 1990; Goldstein \& Keohane, 1993). This institution, as a rule, helps in instant exchanges without having to think out precisely the terms of a deal each time and each occurrence (North, 1993). In North's view, institutional change within stable, informal constraints, consists of three elements: social interface, economic interface, and political interaction.

The stable constraint from the social aspect in UMi policymaking is about exchange relations and outcomes that are not modified fundamentally by 'superficial' daily events that anchor their routines, customs, traditions, and culture (WindhoffHéritier, 1993: 14; Raab \& Kenis, 2007: 190). Bates et al. (1998) highlight the importance of social context and history through analytic narratives to boost rational choice events and outcomes.

\section{Stable Social Interface}

Stable social interface concerns about culture as a mechanism of interaction. The procedures are formal and informal and have limitations that exist in every civilization's past development and must be absorbed (and reflected) by every person in the direction of their socialization (see, e.g., Hodgson, 2005, Hodgson, 2006). Fundamental to the economic analysis of economic change is the nowadays famous distinction between 'formal rules' and 'informal constraints' (North, 1990; for a discussion, see Hodgson, 2006).

Cultural factors consist of culture, subculture, and social classes, particularly in buying behavior. In Indonesia, the cultural influence elaboration toward credit has been studied since the colonial era. 'Pre-capitalism' expressed a theoretical view of rural societies in a state somewhere between an economic system based on the principle of social need satisfaction and one based on capital accumulation. Boeke saw a connection with ethnographic evidence that the Indonesian rural population suffered from a 'chronic credit thirst' based on officials-turned-ethnographers' observations and research about the indigenous population's economic behavior. The 'Adat' Law school, Prof. Van Vollenhoven, and Fokkens influenced Boeke's thesis on the rural population's vulnerability. The prestige spending created chronic credit thirst that drove high demand of consumer's good, being captured by the 'tjina mindring' or Chinese money lender who carried out cruel usury practice (Boeke in Soesilo, 2004). The short-term 
nature of the indigenous people's 'superficially instincts' crave short-term consumptive behavior through usurious interest rates. The external ethnic categories, especially the Chinese, with their racial characteristics using even greater menace to the indigenous population than the Arab usurers, particularly because they were so numerous. Boeke describes the Chinese traders after Fokkens as 'addicted to usury and smuggling' and taking advantage of the 'weakness and ignorance' of farmers by getting hold of their harvests and their land. Based on this argument, Boeke proposed Anti-Usury Law to protect rural people against usury practice during the Dutch ethical policy. They need Dutch intervention in the emancipatory and educative objectives in pastoral and financial matters (Boeke in Soesilo, 2004).

\section{Stable Economic Interface}

The stable cultural factors in Indonesia reflects the Agrobusiness Credit (Kredit Usaha Tani - KUT) management. It was in force from 1996 to 2000 as Ekonomi Rakyat (nu.or.id, 2011), with Adi Sasono as Indonesia's 'Most Dangerous Man' despite his innocuous title as Minister of Small Business and Cooperatives. With IDR 7 trillion of KUT loans in the name of Ekonomi Rakyat, he wanted to crush the powerful commercial conglomerates' economic claw and reallocate prosperity to small businesses and nearly 50,000 predominantly state-run cooperatives (Richburg, 1999). Ironically, some of the KUT debtors were jailed owing to an $81.4 \%$ nonperforming loan. The loan worth IDR 5.7 trillion remained unrecovered since 1998 (Beritasatu, 2012). Several blacklisted KUT debtors are listed in the debtors' information system (SID). They automatically become ineligible for future borrowing, although a few are not even borrowers as their Identity Card (KTP) was fraudulently used by others to receive the KUT. This irony led to Hall Hill's criticism that most Indonesian Ekonomi Rakyat's policy lacks coherence even though it looks provocative and politically attractive (Hill, 2000: 291).

\section{Established Political Interaction}

Politics influence microfinance all over the world. For example, in India, SKS microfinance collapsed due to government intervention in India (Dowla, 2015). Grameen Bank in Bangladesh also suffers from the same problem.

\section{The External System}

\section{Economic External Factor}

'Grameen' refers to a rural village. Muhammad Yunus in Halifax, Canada, in 2006 before he was awarded the Nobel Peace Prize, is a social entrepreneur who believes in prioritizing social value and development versus capturing economic value (Mair \& Lanuza, 2004) through microfinance, whose fundamental tenet is to allow the poor to help themselves. It is also consistent with the principle of the light touch of the government's support (Berry et al., 2001). Muhammad Yunus argued that government 
should withdraw from everything else but law enforcement, the justice system, national defense, and foreign policy, and let a 'Grameenised private sector' take possession of its extra functions (Yunus 2003: 204; Mader, 2015). It radicalizes a political vision of a financing mechanism for public goods and services (Mader, 2015).

\section{UKMC, a University-based Civil Society Organization}

Since the 1980s, neoliberalism perceives higher education as a business operating from within the new knowledge economy (Commisso, 2013; Uzuner-Smith \& Englander, 2015). Since 1990, neoliberalism as the global trend due to expanding world economic competition and trade in higher education services (Naidoo 2011). It influenced more to higher education compared to the public good, public service, or government regulation (Johnstone et al., 1998: 5; Cantwell \& Kauppinen, 2014). However, based on Indonesia's Laws Number 12 Year 2012 about higher education, there are three obligations (Tridharmas) of Indonesia's University. They should be combined teaching, research, and community services.

The UN International Year of Micro Credit in 2005 influenced the establishment of the UKM-Center Faculty of Economic, University of Indonesia (UKMC). This institution focus on community services. The first UKMC activity was the Indonesian Global Micro-entrepreneurship Award. UKMC initiated it in cooperation with UNDP, UNCDF, and Citibank. It was started in 2005 and continued for 11 years recognizing micro-enterprises who borrowed a maximum of Rp10 million (US\$670) for productive works. They received awards together with their account officers.

The UKMC have a partnership with Grameen bank cooperative (Komida) to alleviate poverty based on self-help in 12 Indonesian provinces since 2008 and then advocating the UMi to the government incrementally by showing the exemplars that this concept is a good one. The UMi policy was developed as part of community development and an adaptation of the rural Grameen bank idea as a grassroots entrepreneurs' circular lending policy. UKMC developed the concept for Depok, near the University of Indonesia, in 2009-2010 with inspiration from Koperasi Mitra Dhuafa (Komida) and the Tangerang Regency that managed its local funding using the Grameen Bank concept. Unfortunately, UKMC's idea was turned down by the mayor of Depok, Nur Mahmudi Ismail, but accepted by Jokowi when he was the Mayor of Solo in 2010. However, Jokowi's successor terminated this program in Solo because Jokowi run as Jakarta governor and won. In 2014, Jokowi became president and revived the UMi program.

\section{The Degree of Consensus for Policy Changes}

The public choice theory includes the utility-maximizing behavior of an individual as a 'natural,' rational human behavior (Schneider \& Ingram, 2007: 336). However, the selfinterest economic theory occupies a central place in sociological theories of political 
conflict and political man's action (Lipset, 1960). During policymaking, the political, moral, spiritual, or even idiosyncratic (personal) reputation (North 1991: 104) collate in the form of a 'network' conception of analysis and outcomes (Windhoff-Héritier, 1993: 14, Raab \& Kenis, 2007: 190).

The Nash Equilibrium in game theory is achieved due to the optimal outcome in a game theory when no player is willing to deviate. Institutions facilitate transactions, but they start their negotiation with incomplete information. The serial interface of actors within the commercial setting of scarcity drives the North's institutional change framework. Therefore, competition is key to institutional change. It encourages organizations to continue to capitalize on knowledge to stay in business. The economies of scope, complementarities, and network externalities of an institutional matrix, make institutional change enormously incremental and path dependent (North, 1990). Forester, Healy (1997) and Innes (2003) have encouraged communicative policy analysis. The policy analyst's main task is to ease the process of debate and help planners demonstrate their conversational practices (Gottweis, 2007: 238). It is called 'qualitative interpretive and 'taking language seriously' with highly philosophical presuppositions that 'undergird' these methods (Yanow, 2007: 405). Their contributions help describe, explain, and prescribe modification in public decision-making in harmony with an individualistic, utilitarian form of rationality (Andrew, 2007: 165). Rationality limits the policy model's range of application. However, at times, 'truth' escapes a rationalistic/positivistic policy analyst. Then, policymaking becomes a project of communication (Andrews, 2007: 167).

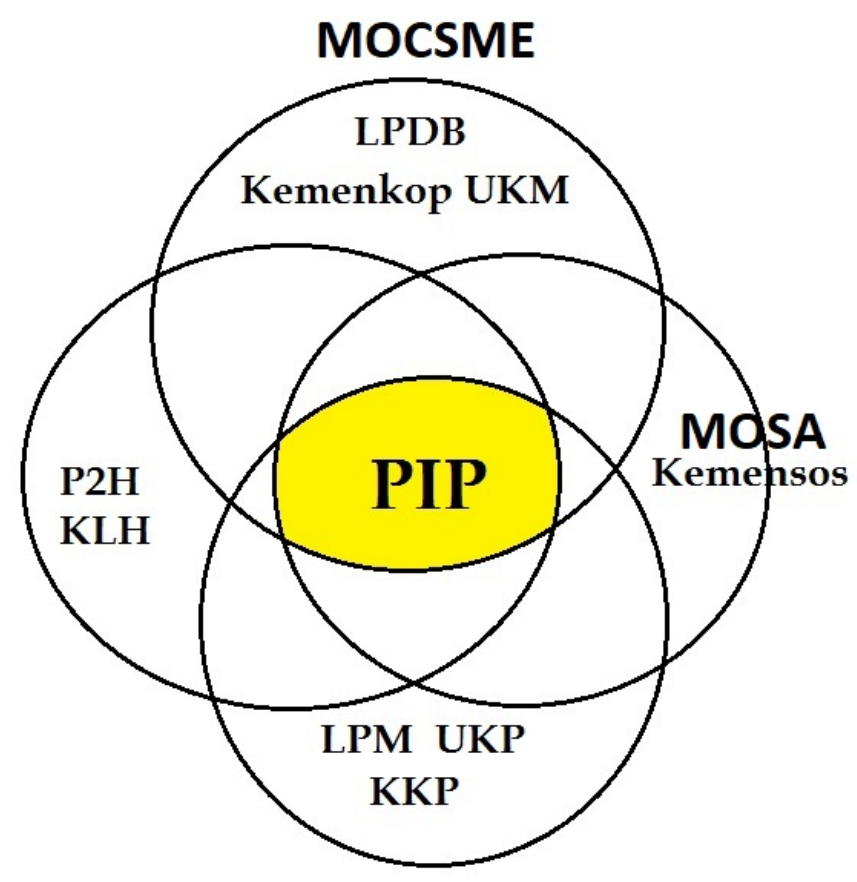

Figure 2. The Position of PIP as Coordinator 
A consensus is an approach emphasizing the interactive and productive role of communication in cognitive processes. This perspective can facilitate normative analysis through an organized dialogue among competing actors to settle normative positions. Unlike the process of pure or abstract thinking, the consensus is a potential agreement with other participants based on critical judgment and communication power (Fischer, 2007: 227).

\section{Getting a Permit}

Since 12 October 2016, the state budget for UMi was IDR 1.5 trillion as written in Law 1, 2016, for the 2017 fiscal year. However, since the PIP was an institution that changed from infrastructure to microfinance function, the Parliament put an asterisk on attachment 1 of the law. This mark implies that the Parliament was still waiting for approval from the MABR under Asman Abnur's leadership. Abnur's staff found bureaucratic disputes over PIP's duplication with other similar BLUs practicing microfinance-for example, the Agency of Circular Fund Management (LPDB) at Ministry of Cooperatives and Small Medium Enterprise (MoCSME). A similar function is found in marine-based microfinance (LPMUKM) from the Ministry of Ocean and Fishery. There is also a microfinance institution $(\mathrm{P} 2 \mathrm{H})$ from the Ministry of Forestry and Environment in the Ministry of Forestry. With the particular niche of government funding below IDR 10 million per entrepreneur spread across 16 ministries, coordination similar to the PIP is essential. It is consistent with the ministerial agreement's spirit on 16 December 2014 to have synergy when managing the micro, small and medium enterprises.

As the UMi funding coordinator, the PIP proposes maintaining the tenet of 'the more you stay away from government, the better.' There are two disbursement schemes. A one-step loan is from PIP to state-own enterprises (SOEs) such as Pegadaian, PNM. The two-step loan when the money is transferred from PIP to Bahana Artha Ventura (an SOE) and then to saving and credit cooperatives. Some of them are Shariah Cooperatives. As of September 2018, 16 cooperatives were disbursing the UMi funding. However, at that time, Asman Abnur's subordinates were unhappy with the PIP concept and challenged PIP's abbreviation that contains the word' investment.' It was considered incompatible with channeling microfinance. Hence, the PIP should change the name.

The ability to persuade is essential in this context. It is a combination of character and the speaker's credibility (ethos), the appeal to the listener's emotion (pathos), as well as in the argument itself (logos) as a mean of instructing and applying reason (Aristotle, 1999) that leads to the performativity nature of the policy process (Gottweis, 2007: 247). UKMC was lucky due to having previous activities with Asman Abnur during the development of the SME's law Number 20 Year 2008 at the Parliament's 
building in Senayan and during West Sumatra's revitalization program after the earthquake, located in Asman Abnur's home town.

After a UKMC's persuasion to Asman Abnur, he ended the dispute. He exercised an element of compulsion, commonly noticed in political entrepreneurship (Holcombe, 2002). It implied that the PIP was allowed to retain its name and function as the UMi coordinator. Based on Asman Abnur's letter, Sri Mulyani Indrawati made another MoF Regulation (PMK) Number 91 Year 2017 about the PIP working procedure on 5 July 2017. As expected, on 26 July 2017, when the MoF met with Parliament and Melchias Markus Mekeng, who led the discussion, 51 parliament members agreed to reallocate PIP funding into the circular fund of IDR 1.5T for the 2017 fiscal year. It was the hallmark of PIP as the UMi coordinator. PIP received another IDR 2.5T on 20 November 2017, based on Law Number 15 Year 2017 at attachment 1 of the state budget for 2018 and IDR 3T for the 2019 fiscal. So the total of UMi funding was IDR 7T.

\section{The Degree of Consensus for Policy Changes}

Cabinet Reshuffles

Bambang Sumantri Brodjonegoro was recruited as a finance minister with no political affiliation (Muhtadi, 2015). To make him stay in the cabinet, he had to make an excellent promise to president Jokowi. Otherwise, he will be reshuffled. He promised a $61 \%$ reduction in energy subsidies would save about IDR 200 trillion of government spending will occur with a capital expenditure increase of IDR 115 trillion; fiscal deficit reduction from $2.3 \%$ to $1.9 \%$ of GDP, which was well below the legal limit of $3.0 \%$ of GDP (Yusuf \& Sumner, 2015). In September and October 2015, Brodjonegoro supported the Coordinating Minister of Economic's five economic policy packages with more than 130 regulation revisions to ease businesses were announced. One of the policies was a new, subsidized KUR credit to support rural MSMEs via banks. Following the hearing with Parliament on 18 July 2016, Brodjonegoro established a decision letter to his subordinates Number S-616/MK/2016 on 25 July 2016 about tailor-made KUR (Ministry of Finance later converted that into the UMi program) and the revival of PIP as the managing institution.

Unfortunately, on 27 July 2016, Bambang Sumantri Brodjonegoro, who was creating the initial UMi's policy via Non-Bank Financial Institution, was replaced by Sri Mulyani Indrawati. It illustrates how Jokowi could drive Indonesia's patronage-driven democracy in a rapid, simple, and ruthless manner in situations of 'statist-nationalist development strategy' (Warburton, 2016). However, Brodjonegoro was fortunate to be posted as the Minister of National Planning Agency (Bapenas). His new post position was started simultaneously as Asman Abnur's inauguration as Minister of the Ministry of Administrative Bureaucratic Reform (MABR) as a coalition compensation to the PAN Party. Previously, PAN was an opposition party, but since this party merged with 
Jokowi's coalition, Jokowi gave this party a ministerial position compensation. Asman Abnur leads the MABR only in one year. It was fortunate that UMi was able to get his permit.

Constraint within the Ministry of Finance $(\mathrm{MoF})$

Creating a UMi policy was not easy because of the changing Minister of the MoF and the internal problem. PIP was an agency institution previously located under the Secretary-General (SG) of the MoF. Based on the annual MOFIN survey to evaluate the MoF's performance, the average SG's performance score in 2014 was 71. That year was the first time MoF's invitation to UKMC was the initial avocation process about the UMi program. SG's score was not the worst performance under the MoF. However, to create better accountability, the Minister should move PIP to DDJPB, whose performance score was the best at the MoF with an average score of 86 . The discrepancy of performance (Figure 3 and 4) created a lengthy process of transfer due to different organizational cultures. It took almost two years. After PIP was already under DJPB, the UMi's policymaking process was progressing faster.

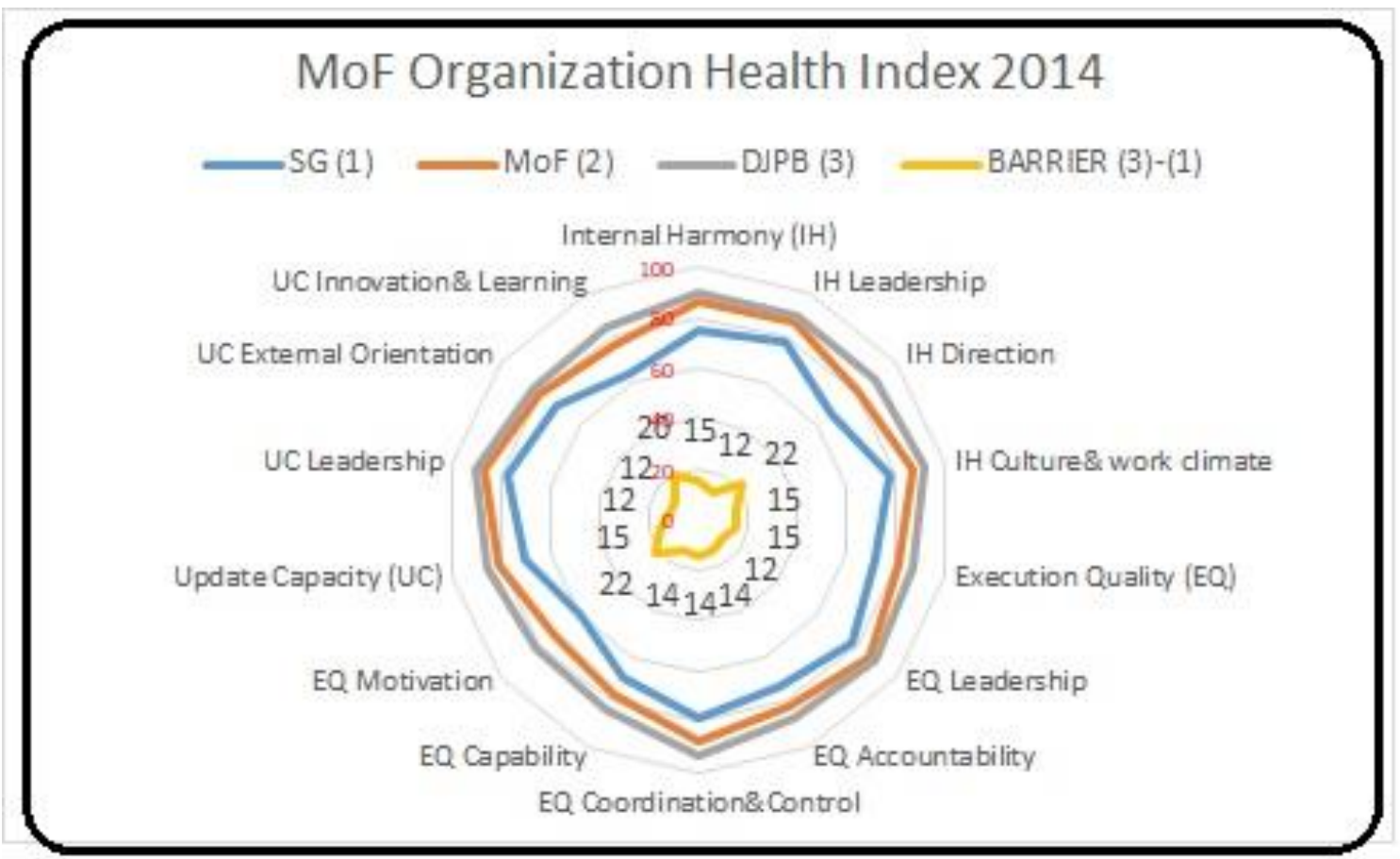

Figure 3. Barrier of PIP's transfer from SG to DJPB 2014 


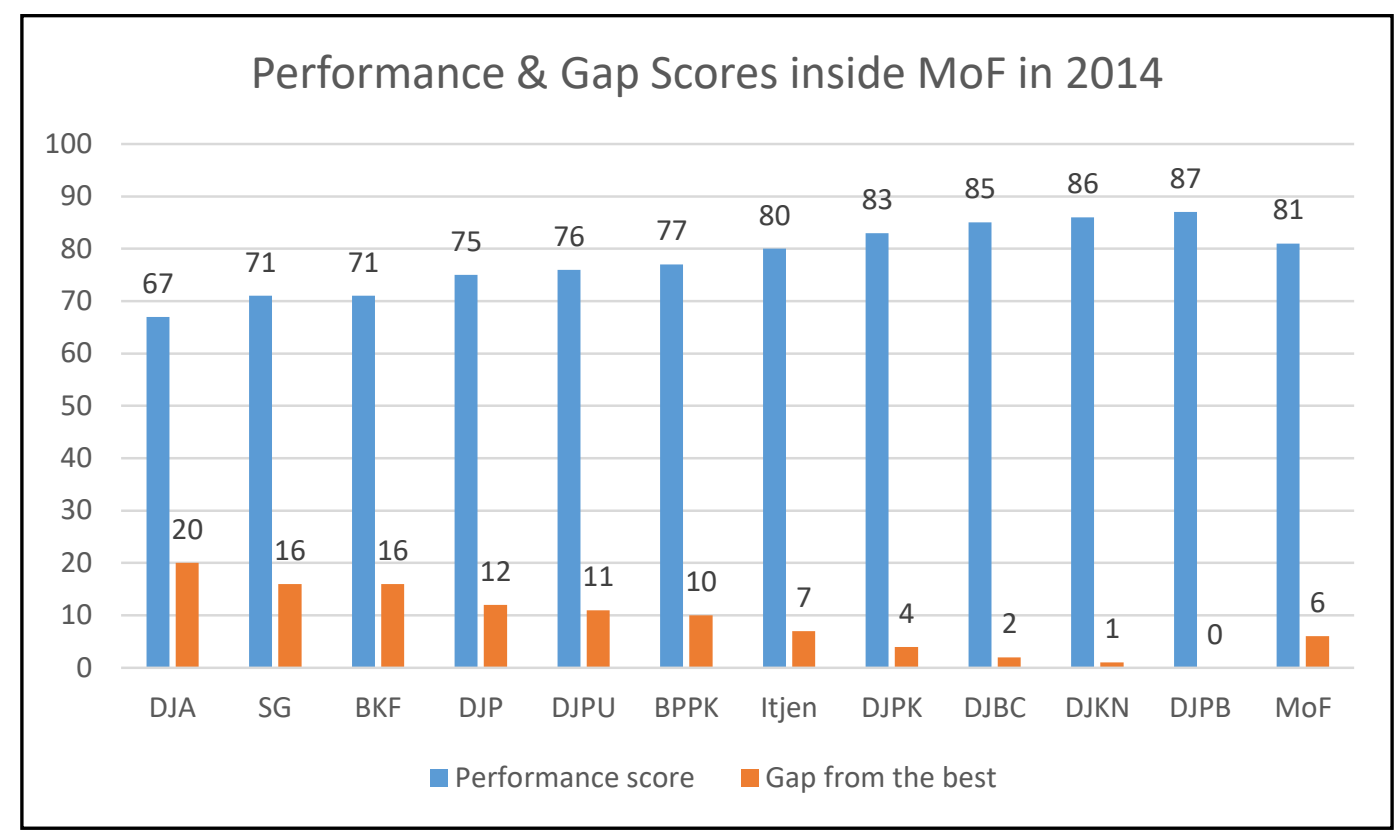

Figure 4. Performance and Gap Scores inside MoF in 2014

Resources of Subsystem Actors

The UMi program initiation is complicated because the parliament members, as Olson's definition about the latent group, have a natural bargaining position to create selective benefits that accrue only to those who contribute to the group enterprise (Lowi et al., 2018). Parliament is an elite enterprise that also has elements of exclusivity. If the parliament member goes to regions, they should be treated like ministers (law Number 9 Year 2010 Chapter 9 article $1 \mathrm{n}$ ). It is called substantive and procedural rationality (Weber, 1922, 1957), with two different legitimacy sources from 'authority and consent' (Andrews, 2007: 162). They have a legitimate public decision foundation based on legal, authoritative, and appropriate context. Therefore, 15 events for parliament member general assessment were planned in 2017 until 2018 to visit their home regions. Their 'exercise of power' is very significant in their confrontational approach to the executives (Fisher, 2007: 226). However, establishing a connection with their constituents, rather than necessarily sharing views, is essential for the parliament members (Crewe, 2018: 17).

To some extent, their face-to-face connection is easily manipulated to match the UMi's necessary entrepreneurial assistance under the disguise of parliamentary public assessment. It is similar to a free political campaign because the UMi program will fund this activity using the state budget. The parliament members expect to receive more votes as a by-product of their hometown visits because some of the UMi's debtors are their constituents. For the incumbents, the repeated meetings with voters will positively influence voter recognition. So they expect to earn the vote again in the 'next election' (Fenno Jr., 1978: 56). Parliament members have the legitimate authority that is often hard to refuse by PIP's partners for funding disbursement in the regions even if the 
debtors are mismatched. A mishap already occurred in Surabaya. A parliament member promised her constituents that the UMi funding would be disbursed with no collateral and no screening. As a result, Pegadaian had to suffer the loss.

\section{Policy Subsystem}

\section{Coalition A: Market Rate Orientation}

Commercial microfinance is based on the liberalism paradigm supported by the Central Bank (BI), Ministry of Finance, and Bappenas (Robinson, 2002). It was a paradigm shift from the traditional approach (subsidized rate), aiming primarily at resolving perceived market failures. Commercial microfinance tends to be associated with high-interest rates, while subsidized credit imposes lower interest rates. For the sake of sustainability, microfinance is allowed to charge high-interest rates to cover its costs. But as microfinance offers limited numbers of small loans to the poor, the cost of credit is expensive. Commercial microfinance is based on a view of the financial system that prefers a market-based, liberalized, and sustainable approach; savings mobilization; orientation toward clients' demands; professional management of costs and risks; and an enabling policy and legal environment.

\section{Coalition B: Subsidized Rate Orientation}

In Indonesia, the Ministry of Agriculture and the Ministry of Cooperatives (Robinson, 2002) support the subsidized rate. Underlying these programs assumes that the rural poor cannot save and that poor households cannot repay market rates of interest; therefore, cheap loans to make new investments are needed. Based on these assumptions, public development banks channeled heavily subsidized funds to selected target groups such as those found in Bangladesh, India, Malaysia, Nepal, Pakistan, Philippines, and Srilanka (Fry, 1995; 435 in Soesilo, 2004).

However, moral hazards are found in the subsidized agriculture credit (KUT), in which the more productive the debtors, the less the repayment of credit. This kind of delinquency and default plagued other countries, such as Bangladesh, India, Korea, and Nepal (Fry, 1995: 436 in Soesilo, 2004). In sum, low subsidized interest rates resulted in unequal income distribution (Fry: 1995: 449) because the wealthier individuals have greater access to cheap credit. This rate also creates credit rationing and weak financial institutions' performance, lower economic growth due to misallocation of resources stemming from financial layering (Indonesia's declining economic growth in 1973-1979 compared to 1968-1973 despite a substantial increase in the investment ratio). It was not due to insufficiency but rather a misallocation of resources that stemmed from financial layering and selective as well as subsidized credit policies (Fry, 1995: 449). Subsidized interest rates did not improve outreach to the poor; on the contrary, they raised serious concerns regarding their sustainability. 


\section{Policy Broker}

The policy broker is UKMC who mediates the paradigm differences that occur between coalition A which is market rate oriented consisting of BI, Ministry of Finance and Bappenas and coalition B which is subsidies oriented, consisting of the Ministry of Cooperatives and SMEs and the Ministry of Agriculture (Robinson, 2002). Using Schneider and Ingram's classification on governments and their political participation models, four policy targets were identified: the advantaged, contenders, dependents, and deviants (Hoppe, 2007: 339). The UMi concept is a loan with a market rate but has necessary entrepreneurial assistance through nonbank financial institutions. A public service agency (BLU), Pusat Investatsi Pemerintah (PIP), under the MoF, manages the state budget for UMi and uses Non-Bank Financial Institutions (NBFIs) such as cooperatives as the PIP's two-step fund disbursement vehicle. Future leveraging is planned based on UMi accountability and transparency to get more funding to expand borrower outreach. The basic proposition of the UMi program is to help the poor become entrepreneurs. It is in line with Berry's light touch of government support (Berry et al., 2001).

Unlike KUT or KUR, UMi follows necessary routine entrepreneurial assistance based on the pro-poor Grameen bank model's fundamental concept but serves men and women. The Know Your Customer (KYC) norms are fulfilled through frequent face-toface meetings. Indonesia emphasized the systematic approach in policymaking, as demonstrated by law Number 12 Year 2011, Presidential Regulation (PP) Number 91 in October 2017, on quick implementation of businesses, as well as the Presidential Instruction (Inpres) Number 7 Year 2017 that demands policy synchronization (Kemenko Perekonomian, 2018). Hence, every policy should have its previous research activities.

There are contextualized economic, political, social, and cultural processes with delineation of policy settings, actors, institutions, and dynamics (Gottweis, 2007). These processes have been explained using four elements of North's institutional change: the stability of institutions, the sources of external or system change, the agents of change, and the direction of change (Faundez, 2016). However, culture, technology, state, and actors' motive for efficiency or self-interest drive institutional change (Groenewegen et al., 2010). According to traditional political power resources and social constructions, there are four policy targets: the advantaged, contenders, dependents, and deviants (Schneider \& Ingram, 1993). The UMi policy provides loans to micro-entrepreneurs using the state budget. They can be categorized as dependents with 'good' individuals even though they are vulnerable, defenseless, and deficient in political power resources. The UMI funding program is a 'win-win' framework between KUR and UMi. It merges the three main actor groups' interests (Mader, 2015). First, the KUR does not lend to a 
poor borrower who takes a loan and buys access to goods to start their business with the sale or provision of social services in an add-on bundling activity with compulsory empowerment. Second, the NBFIs differ from banks in that although both impose a lender's interest (margin) conventionally, or 'nisbah' according to Syariah principle, to pay for all activities. Third, unlike a bank, the PIP is projected as a funding coordinator who assumes the microfinance of by-products such as the desired sustainable building trust and social peace despite the limited state budget.

\section{Policy Output}

On 4 November 2016, MoF with OJK (Financial Service Authority) and Bank Indonesia created the UMi database as part of the KUR's information system (SIKP). On 18 November 2016, President Jokowi launched the SNKI (the new National Financial Inclusion Strategy), based on Presidential Regulation Number 82 Year 2016, to reach $75 \%$ of adults with transactions by the end of 2019 (Okezone, 2016, World Bank, 2017).

On 23 February 2017, Sri Muyani Indrawati signed the PMK Number 22 Year 2017 on UMi consisting of 14 chapters and 28 articles that employ the 34 regional representatives (Kakanwil) and 182 State Treasury Service Offices (KPPNs) in the regions to monitor the UMi funding activities. It follows the KYC norms and 'economies of scene' (Provost, 2000), which require propinquity with credit recipients and uphold the principle of state finance and accountability. KPPN is spread across several areas, such as 49 in Sumatra, 58 in Java, 21 in Kalimantan, 25 in Sulawesi, 13 in Bali Nusa Tenggara, and 16 in Maluku and Papua, as stated in the PMK 262/PMK.01/2016. The approval from the MABR for PIP is yet to be received even after the introduction of PMK 22/2017.

To facilitate the smooth operation of the UMi program, the PIP supervisory board consists of the MoF and the deputies from the Ministry of Social Affairs (MOSA) and the Ministry of Cooperatives and SMEs (MCSME). On 26 April 2018, UKMC met Idrus Marham (IM) from the Golkar Party after he was appointed as Minister at MOSA on 17 January 2018 (Ihsanuddin, 2018) as a coalition compensation, similar to those given to Asman Abnur from the PAN Party who fled from KMP. The discussion was about UMi funding for a scholarship for bright children, primarily from low-income families, in the MOSA's Hope Family Program (PKH) to enable study at high-ranking universities. However, this idea still needs parliamentary approval. Unfortunately, four months after the meeting, Idrus Marham resigned on 24 August 2018 because the KPK (Commission of Corruption Eradication) detained him as a suspect in a corruption case (Jordan, 2018). Hence, the scholarship proposal stalled.

Policy Impacts

A comparative public policy being used in OECD countries (Saretzki, 2007: 597) is the Regulatory Impact Analysis (RIA) and the World Bank's Ease of Doing Business. 
Regulatory Impact Analysis (RIA) for UMi was done through the piloting process from 2017 to 2018. It is not similar to Mayntz's or Lasswell's problem-oriented policy framework (Scharpf, 1997; 10-12). After one year of UMi piloting, UKMC created a survey by asking 2000 respondents. This survey is matched to the happiness index based on the Findex Survey by World Bank. It is found that UMi created a happy atmosphere for the UMi debtor. Using econometric exercise, based on a model of Happines=f (Umi program Dummy, Food Expenditure, Empowerment Dummy, and Empowerment Duration), it is found that Umi creates a significant change.

Table 1. The Magnitude of Influence of UMi based on UMi's Debtor's Perception

\begin{tabular}{ll}
\hline Independent Variable & The Magnitude of Influence \\
\hline UMi Dummy & $0.41^{*}$ \\
Food Expenditure & 0.04 \\
Coaching Dummy & $0.40^{* *}$ \\
Coaching Duration & 0.00 \\
Change & $0.295^{* * *}$ \\
\hline
\end{tabular}

Notes: significance: ${ }^{* *}$ ) under $1 \%$ error, ${ }^{* *}$ ) under $5 \%$ error, and ${ }^{*}$ ) under $10 \%$ error

Source: UKMC's report to the PIP 2018

After a good result of UMi piloting, on 18 August 2018, Indrawati launched the new PMK Number 95 Year 2018 on UMi with ten chapters and 28 articles to improve over the previous PMK Number 22 Year 2017. It was based on the UKMC finding during the UMi pilot evaluation. In September 2018, the number of UMi debtors in Indonesia stood at 404,282 people with an average loan of IDR 2,82 million. The total disbursements are IDR 1,140,242,258,952. At that time, UMi funding spread to Sumatra (27.5\%), Java (65.9\%), Kalimantan (1.32\%), Sulawesi (2.01\%), Bali (0.1\%), Nusa Tenggara (2.86\%), Maluku \& North Maluku (0.1\%), and Papua \& West Papua (0.16\%).

To sum up the analysis and discussion, Hodgson (2005: 95) discusses that developing institutions have to engage in a 'judicious combination' of comprehensive legislation with synchronized struggles to boost the change of practices and other casual cultural characteristics in line with policy goals. Legislation cannot run quicker than the progress of human behaviour and everyday social norms. A cultural approach can contribute by illuminating priorities after scrutinizing the insights concerning the sustainability of reforms in specific sectors by taking into account formal institutions. Due to discrepancy of arguments from research institutions, government, parliament, and interest groups to cater to unserved 46.7 million grassroots entrepreneurs from bank-based KUR; hence, ACF can moderate goal disagreement to find a solution due to its good structure to recognize and describe belief and policy change with technical disputes in several levels (Hoppe \& Peterse, 1993). 


\section{Conclusion}

Ultra Micro-lending (UMi) policymaking is a nine-year process from its conception to the Ministry of Finance's (MoF) adoption due to the need to show the exemplar that made the MoF convinces that the concept is workable. Albeit Advocacy Coalition Framework (ACF) can moderate goal disagreement to find a solution; still, the iteration in this framework creates a limitation in preserving the program's mission due to the external factor's dynamic. For example, in 2020, PIP raised the maximum credit ceiling of UMi from IDR 10 million to IDR 20 million due to political pressure. This doubles amount from the original concept might induce UMi's mission drift due to the potential reluctance to serve the grassroots who need only a very small amount of money. Further studies are strongly suggested to conduct research on evaluating and monitoring the UMi policymaking as a continuous effort to ensure that the program is effective and beneficial, as well as contributes to the economic development of the country.

\section{Author's Declaration}

The author made substantial contributions to the conception and design of the study. The author took responsibility for interpretation and discussion of this study. The author read and approved the final manuscript. If there is any flaw in the writing, it is entirely my mistake.

\section{Acknowledgement}

This research was funded by the University of Indonesia. The Author would like to thanks the UKMC's piloting team (Zakir Mahmud, Permata Wulandari, Dewi Sukma, Miqdad Rabbani, Aminah). Also special thanks to Marwanto Harjowiryono, Ari Wahyuni, Djoko Hendratto from DJPB Ministry of Finance, Syahrir Ika and Ririn Kadariyah from the PIP Ministry of Finance.

\section{ORCID}

Nining I Soesilo (1) https://orcid.org/0000-0002-0890-3314

\section{References}

Aji, P. (2015). Summary of Indonesia's Poverty Analysis. ADB, Manila. Retrieved August 29, 2018, from https://www.adb.org/sites/default/files/publication/177017/inopaper-04-2015.pdf

Andrews, C. J. (2007). Rationality in Policy Decision Making. In C. J. Andrews, F. Fischer, G. J. Miller, \& M. S. Sidney (Eds.), Handbook of Public Policy Analysis: Theory. Politics and Method (pp. 161-185). Boca Raton, Florida 33487-2742, USA: CRC Press, Taylor and Francis Group.

Aristotle. (1999). Nichomachean Ethics. (W. Ross, Trans.) Batoche Books Kitchener. Retrieved from https://socialsciences.mcmaster.ca/econ/ugcm/31l3/aristotle/Ethics.pdf 
Balisacan, A. M., Pernia, E. M., \& Asra, A. (2002). Revisiting Growth and Poverty Reduction in Indonesia: What Do Subnational Data Show? Asian Development Bank (ADB), Economics and Research Department. Manila: ERD Working Paper Series, No. 25. doi:http://hdl.handle.net/11540/2066

Bappenas. (2014). Laporan Pencapaian Tujuan Pembangunan Milenium di Indonesia 2014. Retrieved from Scribd: https://www.scribd.com/doc/294394332/Laporan-MDGs2014-Final

Bates, R., Greif, A. L., Rosenthal, J.-L., \& Weingast, B. (1998). Analytic Narratives. Princeton, NJ: Princeton University Pres.

Bates, R., Greif, A., Levi, M., Rosenthal, J.-L., \& Weingast, B. (2000). The Analytic Narrative Project. American Journal of Political Science, 94, 696-702.

Beritasatu. (2012). Pemerintah Kejar Tunggakan KUT Rp5,7 Triliun. Retrieved from beritasatu: http://www.beritasatu.com/makro/66314-pemerintah-kejartunggakan-kut-rp5-7-triliun.html

Berry, A., Rodriguez, E., \& Sandee, H. (2001). Small and Medium Enterprise Dynamics in Indonesia. Bulletin of Indonesia Economic Studies, 37, (3), 363-384. doi:10.1080/00074910152669181

Brueckner, M., \& Lederman, D. (2015). Effects of Income Inequality on Aggregate Output. World Bank Group, Latin America and the Caribbean Region. Washington DC: World Bank. Retrieved May 21, 2018, from http://documents.worldbank.org/curated/en/291151468188658453/pdf/WPS7317. pdf

Cantwell, B., \& Kauppinen, I. (2014). Academic Capitalism in Theory and Research. In B. Cantwell, I. Kauppinen, B. Cantwell, \& I. Kauppinen (Eds.), Academic Capitalism in the Age of Globalization, (pp. 3-7). Baltimore, USA: Johns Hopkins University Press.

Commisso, G. (2013). Governance and conflict in the university: The mobilization of Italian researchers against neoliberal reform. Journal of Education Policy, 28(2), 157-177.

Crewe, E. (2018). Ethnographies of parliament: culture and uncertainty in shallow democracies. Journal of Organizational Ethnography, 7 (1), 16-30. doi:https://doi.org/10.1108JOE-11-2017-0057

Dowla, A. (2015). Political Interference in Microfinance. Enterprise Development and Microfinance, 25(4). doi:10.3362/1755-1986.2015.029

Faundez, J. (2016). Douglass North's Theory of Institutions: Lessons for Law and Development. Hague J Rule Law, 8, 373-419. Retrieved May 24, 2018, from http://wrap.warwick.ac.uk/84086

Fenno Jr, R. F. (1978). Home Style: House Members in Their Districts. Boston and Toronto: Little, Brown and Co.

Fischer, F. (2007). Deliberative Policy Analysis as Practical Reason: Integrating Empirical and Normative Arguments. In C. J. Andrews, F. Fischer, G. J. Miller, \& M. S. Sidney (Eds.), Handbook of Public Policy Analysis (pp. 223-236). Boca Raton, Florida, USA: CRC Press, Taylor and Francis Group. 
Fry, M. (1995). Money, Interest and Banking in Economic Development (2nd ed.).

Baltimore: The John Hopkins University Press.

Goldstein, J., \& Keohane, R. (1993). Ideas and Foreign Policy: Belief, Institutions, and Political Change. Ithaca, NY: Cornell University Press.

Gottweis, H. (2007). Rhetoric in Policy Making: Between Logos, Ethos, and Pathos. In F. Fischer, G. J. Miller, \& M. S. Sidney (Eds.), Handbook of Public Policy Analysis, Theory, Politics and Methods (pp. 237-250). Boca Raton, Florida 33487-2742, USA: CRC Press.

Groenewegen, J., Spithoven, A., \& Van Den Berg, A. (2010). Institutional Economics, An Introduction. New York: Palgrave Macmillan.

Healy, P. (1997). Collaborative Planning. London : Macmillan.

Hill, H. (2000). The Indonesian Economy. Cambridge: Cambridge University Press.

Hodgson, G. M. (2005). 'Institutions and Economic Development: Constraining, Enabling and Reconstituting'. In S. d. Dymski, Reimagining Growth Towards a Renewal of Development Theory (pp. 85-98). London: Zed Books: Zed Books.

Hodgson, G. M. (2006). What are Institutions? Journal of Economic Issues, 40(1), 1-25.

Holcombe, R. G. (2002). Political Entrepreneurship and the Democratic Allocation of Economic Resources. The Review of Austrian Economics, 15(12/3), 143-159.

Retrieved from https://link.springer.com/article/10.1023\%2FA\%3A1015758419984

Hoppe, R. (2007). Applied Cultural Theory: Tool for Policy Analysis. In F. J. Fischer, G. J. Miller, \& M. S. Sidney (Eds.), Handbook of Public Policy, Theory, Politics and Methods (pp. 289-308). Boca Raton, Florida 33487-2742, USA: CRC Press, Taylor and Francis Group.

Hoppe, R., \& Peterse, A. (1993). Handling Frozen Fire. Boulder, CO: Westview Press. Ihsanuddin. (2018). Idrus Marham yang Akhirnya Jadi Pak Menteri... Retrieved from Kompas.com: https://nasional.kompas.com/read/2018/01/17/16585471/idrusmarham-yang-akhirnya-jadi-pak-menteri

Innes, J. J. (2003). Collaborative Policy Making: Governance through Dialogue. In M. Hajer, H. Wagenaar, M. Hajer, \& H. Wagenaar (Eds.), Deliberative Policy Analysis: Understanding Governance in the Network Society. Cambridge: Cambridge University Press.

Johns, P. (2003). Is there life after policy streams, advocacy coalitions, and punctuations: Using evolutionary theory to explain policy change? Policy Studies Journal, 31(4), 481-498.

Johnstone, B., Alka, A., \& Experton, W. (1998). The Financing and Management of Higher Education: A Status Report on Worldwide Reforms. Washington, DC: World Bank.

Jordan, R. (2018). Agus Gumiwang Resmi Dilantik Jadi Mensos Gantikan Idrus Marham. Retrieved from Detik.com: https://news.detik.com/berita/d-4180769/agusgumiwang-resmi-dilantik-jadi-mensos-gantikan-idrus-marham

Kemenko Perekonomian. (2018). Workshop Implementasi Regulatory Impact Analysis (RIA) di Indonesia. Retrieved from www.ekon.go.id: https://www.ekon.go.id/berita/view/workshop-implementasi.3771.html

Lipset, S. M. (1960). Political man: The Social Bases of Politics. Garden City, New York: Doubleday. Retrieved September 2, 2018, from 
https://archive.org/stream/politicalmansoci00inlips/politicalmansoci00inlips_djv u.txt

Lowi, Ginsberg, Shepsle, \& Ansolabehere. (2018). American Government (12 ed.). W.W. Norton \& Company Inc. Retrieved August 18, 2018, from

http://wwnorton.com/college/polisci/americangovernment12/full/ch/01/outline.aspx

Mader, P. (2015). The Political Economy of Microfinance, Financializing Poverty. Palgrave MacMillan.

Mair, J., \& Lanuza, I. M. (2004). Social entrepreneurship: What are we talking about? A framework for future research. Retrieved from Research Gate: https://www.researchgate.net/publication/4817078_Social_entrepreneurship_Wh at_are_we_talking_about_A_framework_for_future_research

Muhtadi, B. (2015, Nov 29). Jokowi's First Year: A Weak President Caught between Reform and Oligarchic Politics. Bulletin of Indonesian Economic Studies, 51:3, 349368. doi:10.1080/00074918.2015.1110684

Naidoo, R. (2011). Introduction to Part II. In R. King, S. Marginson, \& R. Naidoo (Eds.), Handbook on Globalization and Higher Education (pp. 171-178). Cheltenham: Edward Elgar.

North, D. C. (1990). Institutions, Institutional Change and Economic Performance. Cambridge: Cambridge University Press.

North, D. C. (1991). Institutions. Journal of Economic Perspectives, 5(1), 97-112.

North, D. C. (1993). Institutions and Economic Performance. In D. C. North, \& B. G. Uskali Mäki (Ed.), Rationality, Institutions and Economic Methodology (pp. 257-265). London and New York: Routledge.

nu.or.id. (2011). KUT Tak Sejahterakan Petani. Retrieved August 23, 2018, from nu.or.id: http://www.nu.or.id/post/read/27461/kut-tak-sejahterakan-petani

Okezone.com. (2016). Hari Ini, Presiden Jokowi Luncurkan Program SNKI. Retrieved from News.okezone.com :

https://news.okezone.com/read/2016/11/18/337/1544591/hari-ini-presiden-jokowiluncurkan-program-snki

Panda, D. K. (2016). Trust, Social Capital, and Intermediation Roles in Microfinance and Microenterprise Development. Voluntas, 27, 1242-1265. doi:DOI 10.1007/s11266-015-9678-8

Power, C. N., \& Maclean, R. (2013). Lifelong Learning: Meanings, Challenges, Opportunities. In R. Maclean, M. R., J. S., \& S. J. (Eds.), Skills Development for Inclusive and Sustainable Growth in Developing Asia-Pacific, Technical and Vocational Education and Training: Issues, Concern and Prospects (pp. 29-42). Dordrecht: Springer Dordrecht. doi:10.1007/978-94-007-5937--4_2

Raab, J., \& Kenis, P. (2007). Taking Stock of Policy Networks: Do They Matter? In F. Fischer, \& G. J. Sidney (Eds.), Handbook of Public Policy Analysis: Theory, Politics and Methods (pp. 187-200). Boca Raton, Florida 33487-2742, USA: CRC Press, Taylor and Francis Group.

Richburg, K. B. (1999). Indonesia's 'Most Dangerous Man'. Retrieved August 16, 2018, from The Washington Post: 
https://www.washingtonpost.com/archive/politics/1999/03/02/indonesias-mostdangerous-man/407061e7-495d-4620-91ca9b0817810b45/?noredirect=on\&utm_term=.eb04dffa9cf7

Robinson, M. S. (2002). Microfinance Revolution: Lessons From Indonesia (Vol. 2). World Bank. Retrieved from http://documents1.worldbank.org/curated/en/524471468044690635/pdf/multi0pa ge.pdf

Sachs, J. D., McArthur, J. W., Schmidt-Traub, G., Kruk, M., Bahadur, C., Faye, M., \& McCord, G. (2004). Ending Africa's Poverty Trap. Brookings papers on economic activity(1), 117-216. Retrieved from https://www.jstor.org/stable/3217964

Saretzki, T. (2007). The Policy Turn in German Political Science. In F. Fischer, \& G. J. Sidney (Eds.), Handbook of Public Policy Analysis: Theory. Politics and Method (pp. 587- 602). Boca Raton, Florida 33487-2742, USA: CRC Press, Taylor and Francis Group.

Schlager, E. (1995). Policy making and collective action: Defining coalitions within the advocacy coalition framework. Policy Science, 28, 242-270.

Schlager, E., \& Blomquist, W. (1996). A comparison of three emerging theories of the policy process. Political Research Quarterly. Political, 651-672.

Schneider, A. L., \& Ingram, H. (1993, June). Social Construction of Target Populations. American Political Science Review.

Schneider, A. L., \& Ingram, H. (2007). Public Policy and Democratic Citizenship: What Kinds of Citizenship Does Policy Promote? In F. Fischer, G. J. Miller, \& M. S. Sidney (Eds.), Handbook of Public Policy:Theory, Politics and Methods (pp. 329-348). Boca Raton, Florida 33487-2742, USA: CRC Press, Taylor and Francis Group.

Soesilo, N. I. (2004). The Optimal Lending rate of Bank Perkreditan Rakyat (BPR). Bulletin of Economic, Monetary and Banking, 555- 583. Retrieved from https://www.bemb-bi.org/index.php/BEMP/article/view/124/99

UKMC FEB UI. (2019). Laporan Hasil Uji Coba UMi 2017-2018. Depok: UKMC FEB UI.

Uzuner-Smith, S., \& Englander, K. (2015). Exposing ideology within university policies: A critical discourse analysis of faculty hiring, promotion and remuneration practices. Journal of Education Policy , 30(1), 62-85.

Warburton, E. (2016). Jokowi and the New Developmentalism. Bulletin of Indonesia Economic Studies, 52:3, 297-320. doi:10.1080/00074918.2016.1249262

Weber, M. (1922, 1957). The Theory of Social and Economic Organization. New York: Free Press. New York: Free Press.

Weible, C. M., \& Sabatier, P. A. (2007). A Guide to the Advocacy Coalition Framework. In C. J. Andrews, F. Fischer, G. J. Miller, \& M. S. Sidney, Handbook of Public Policy Analysis: Theory. Politics and Method (pp. 123 - 136). Boca Raton, Florida, USA: CRC Press, Taylor and Francis Group.

Windhoff-Héritier, A. (1993). Policy Network Analysis. In H. Keman, \& H. Keman (Ed.), Comparative Politics Directions in Theory and Method (pp. 143-160).

Amsterdam: University Press.

World Bank. (2017). Indonesia - Financial Sector Assessment - World Bank Documents. Retrieved from worldbank.org: 
documents.worldbank.org/curated/en/.../Indonesia-FSAP-Update-FSA07072017.doc

Yanow, D. (2007). Qualitative-Interpretive Methods in Policy Research. In F. Fischer, \& G. J. Sidney (Eds.), Handbook of Public Policy Analysis (p. 405). Boca Raton, Florida 33487-2742, USA: CRC Press, Taylor and Francis Group.

Yunus, M. (2003). Banker To The Poor: Micro-Lending and the Battle Against World Poverty. New York: Public Affairs.

Yusuf, A. A., \& Sumner, A. (2015). Growth, Poverty, and Inequality Under Jokowi. Bulletin of Indonesia Economic Studies, 51(3), 323-348.

doi:https://doi.org/10.1080/00074918.2015.1110685 